\title{
PERENCANAAN MAXIMUM POWER POINT TRACKING (MPPT) DENGAN METODE PERTURB AND OBSERVE PADA PANEL SURYA
}

\author{
Akhmad Fauzi ${ }^{*}$, Mochammad Facta, Sudjadi \\ Departemen Teknik Elektro, Universitas Diponegoro \\ J1. Prof. Sudharto, SH, Kampus UNDIP Tembalang, Semarang 50275, Indonesia \\ ${ }^{*}$ E-mail: akhmad_fauzi@student.undip.ac.id
}

\begin{abstract}
Abstrak
Potensi energi matahari di Indonesia sangat melimpah, hal ini menguntungkan dalam pembangkitan energi listrik dengan panel surya. Energi matahari yang tidak tetap membuat efektitifitas panel surya berkurang. Terdapat dua metode dalam memaksimalkan keluaran panel surya yaitu, metode dinamis dengan menggunakan motor listrik untuk mengarahkan panel surya ke matahari dan metode statis atau Maximum Power Point Tracking (MPPT) menggunakan konverter daya. MPPT digunakan untuk mencari titik daya maksimum dari kurva karakteristik P-V pada panel surya. Pengaruh perubahan irradiasi dan suhu sehingga titik daya maksimum panel surya berubah-ubah. Pada penelitian ini dilakukan perancangan MPPT dengan metode Perturb and Observe (P\&O) dengan Buck Boost Converter untuk mencari titik daya maksimum panel surya. Pada pengujian sistem didapatkan hasil sistem MPPT mampu mencari titik daya maksimum surya sebesar 5.71 watt pada irradiasi 1000 watt $/ \mathrm{m}^{2}$ temperatur $29^{\circ} \mathrm{C}$, sedangkan tanpa MMPT rata-rata daya maksimum pada beban $50 \Omega$ sebesar 5,22 watt, $39 \Omega$ sebesar 4,99 watt. Irradiasi 750 watt $/ \mathrm{m}^{2}$ temperatur $29^{\circ} \mathrm{C}$ dengan MPPT mampu mencari titik daya maksimum surya sebesar 3.92 watt,sedangkan tanpa MPPT rata-rata daya maksimum pada beban $50 \Omega$ sebesar 3.56 watt, $39 \Omega$ sebesar 3.38 watt.
\end{abstract}

Kata kunci: Maximum Power Point Tracking, Perturb and Observe, Buck Boost Converter

\begin{abstract}
Renewable energy is one of the alternative energy. One of them is solar energy. The potential of the solar energy in Indonesia is very big. This phenomenon is profitable in power plant system using solar cell. However, the unconstant of the solar energy make the reduce the effectiveness of the solar cell. To overcome it, there are two method than can be used to maximize solar cell output. They are dinamic method which use electric motor to make the solar panel face the sun and static method or Maximum Power Point Tracking (MPPT) which use power converter. MPPT is used to find out the maximum power point of power from the P-V curve on the solar cell. The effect of the irradiation changes and temperature make the maximum power point of the solar cell changes. In this research, the researcher did a MPPT plan using Perturb and Observe (P\&O) method with Buck Boost Converter to find out the maximum power point of the solar cell. On the system test, the result showed that MPPT system can find out the maximum power point in 5.71 watt on the irradiation $1000 \mathrm{watt} / \mathrm{m}^{2}$ and on the temperature $29^{\circ} \mathrm{C}$. Meanwhile, without using MPPT, the average maximum power with the resistor $50 \Omega$ is 5.22 watt, $39 \Omega$ is 4.99 watt. On the irradiation 750 watt $/ \mathrm{m}^{2}$ and on the temperature $29^{\circ} \mathrm{C}$ using MPPT can track the maximum power point of the solar 3.92 watt, meanwhile without using MPPT, the average maximum power with the resistor $50 \Omega$ is 3.56 watt, $39 \Omega$ is 3.38 watt.
\end{abstract}

Keywords: Maximum Power Point Tracking, Perturb and Observe, Buck Boost Converter

\section{Pendahuluan}

Dewasa ini, Kondisi geografis Indonesia termasuk dalam daerah yang beriklim tropis maka potensi dari sinar matahari cukup melimpah setiap harinya sehingga dapat dimanfaatkan untuk membangkitkan energi listrik. PLTS merupakan teknologi yang ramah lingkungan karena tidak melepaskan polutan seperti halnya pembangkit listrik tenaga fosil [1]. Pemanfaatan panel surya sebagai pembangkit biasanya dapat dihubungkan langsung dengan beban tanpa konverter. Hal ini mengakibatkan beban menerima tegangan yang sama dengan panel surya sehingga beban menerima tegangan yang tidak sesuai dengan tegangan kerja yang diperlukan [2].

Permasalahan yang terdapat pada saat penggunaan panel surya adalah pembangkitan listrik yang rendah serta pada kondisi radiasi yang rendah dan besarnya daya listrik yang dibandingkitkan berubah-ubah seiring dengan perubahan cuaca dan temperatur. Panel surya dapat di optimalkan 
dengan menggunakan 2 metode yaitu metode dinamis dan statis. Metode dinamis menggunkan motor listrik untuk mengarahakan panel surya ke matahari, sehingga irradiasi matahari yang di terima panel surya dapat maksimum. Metode statis atau Maximum Power Point Tracking (MPPT) menggunakan konverter daya untuk mencari titik daya maksimum pada kurva karakteristik panel surya, namun irradiasi matahari yang diterima panel surya metode statis tidak sebesar metode dinamis. MPPT digunakan untuk mencari titik daya maksimum dari kurva karakteristik P-V pada panel surya. Maximum Power Point Tracking (MPPT) terdiri dari 2 bagian utama, yaitu konverter DC-DC dan metode algoritma MPPT [3].

Berbagai metode algoritma telah dipaparkan Trishan Esram dan Patrick L. Chapman, antara lain Incremental Conductance, Perturb and Observe (P\&O), Fuzzy Logic dan lain-lain. Semua algoritma tersebut berbeda aspek termasuk kesederhanaan, kecepatan, implementasi hardware, sensor yang dibutuhkan, efektifitas, dan parameter yang dibutuhkan [4]. Algoritma P\&O akan meningkatkan atau menurunkan tegangan panel surya dengan bantuan konverter secara terus menerus berdasarkan perbandingan daya hingga mencapai Maximum Power Point [5].

Penelitian ini dilakukan Perencanaan Maximum Power Point Tracking (MPPT) dengan Metode Perturb and Observe (P\&O) pada Panel Surya. Penelitian ini memfokuskan pada sistem pencarian titik daya maksimum menggunakan metode Perturb and Observe $(\mathrm{P} \& \mathrm{O})$ yang kemuadian diaplikasikan dalam rangkaian tipe Bucks Boost Converter.

\section{Metode}

Perancangan MPPT terdapat 4 sub sistem, yaitu modul panel surya, rangkaian daya, rangkaian kontrol dan Algoritma MPPT. blok diagram sistem MPPT terlihat pada Gambar 1.

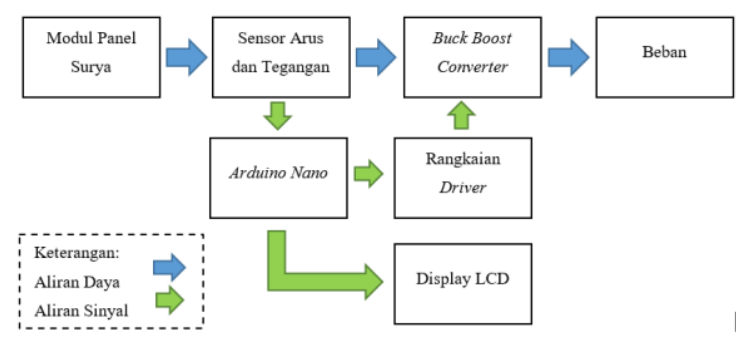

Gambar 1. Blok diagram sistem MPPT

\subsection{Perancangan Modul Panel Surya}

Modul panel surya yang digunakan adalah tipe monocrystalline. Berikut adalah spesifikasi modul panel surya yang digunakan.
Tabel 1. Spesifikasi Panel Surya

\begin{tabular}{cc}
\hline Spesifikasi & Nilai / Keterangan \\
\hline Cells Material & Mono \\
Daya Optimal $\left(P_{\max }\right)$ & $25 \mathrm{~W}$ \\
Arus Operasi Optimal $\left(V_{m p}\right)$ & $1.39 \mathrm{~A}$ \\
Tegangan Operasi Optimal $\left(I_{m p}\right)$ & $18 \mathrm{~V}$ \\
Arus Hubung Singkat $\left(I_{s c}\right)$ & $1.53 \mathrm{~A}$ \\
Tegangan Hubung Buka $\left(V_{o c}\right)$ & $21.52 \mathrm{~V}$ \\
\hline
\end{tabular}

Penelitian yang dilakukan dalam kondisi panel surya yang berada dalam kotak tertutup. Lampu halogen ditempatkan pada sisi atas kotak tepat diatas panel surya yang diamati.

\subsection{Perencanaan Rangkaian Daya}

Perencanan rangkaian daya dalam Penelitian ini menggunakan buck boost converter yang berfungsi sebagai mengubah level tegangan DC, baik ke level lebih tinggi maupun lebih rendah dari tegangan masukan. Buck boost converter dipilih karena tegangan dari panel surya selala berubah berdasarkan radiasi sehingga dapat menaik turunkan tegangan masukan sesuai dengan yang diinginkan. Parameter yang digunakan daam perencanaan buck boost converter sebagai berikut.

Tabel 2. Parameter perencanaan buck boost converter

\begin{tabular}{cc}
\hline Parameter & Nilai \\
\hline Tegangan Masukan & $18 \mathrm{~V}$ \\
Tegangan Keluaran & $14 \mathrm{~V}$ \\
Arus maksimum & $1.5 \mathrm{~A}$ \\
Frekuensi & $20 \mathrm{kHz}$ \\
\hline
\end{tabular}

Terdapay 4 komponen utama dalam buck boost converter yaitu Metal Oxide Semiconductor Field Effect Transistor (MOSFET), dioda, induktor, kapasitor dan resistor sebagai beban. MOSFET digunakan sebagai komponen switching yang dikontrol menggunakan PWM.

Tabel 3. Komponen rangkaian buck boost converter

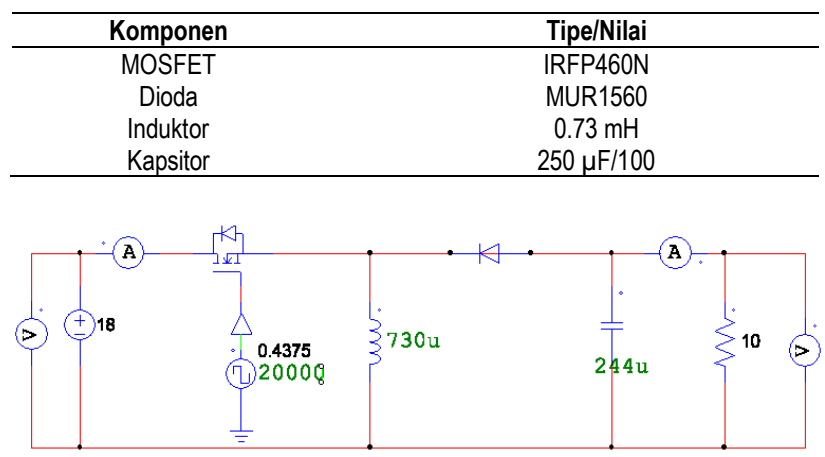

(a) Simulasi rangkaian buck boost converter 


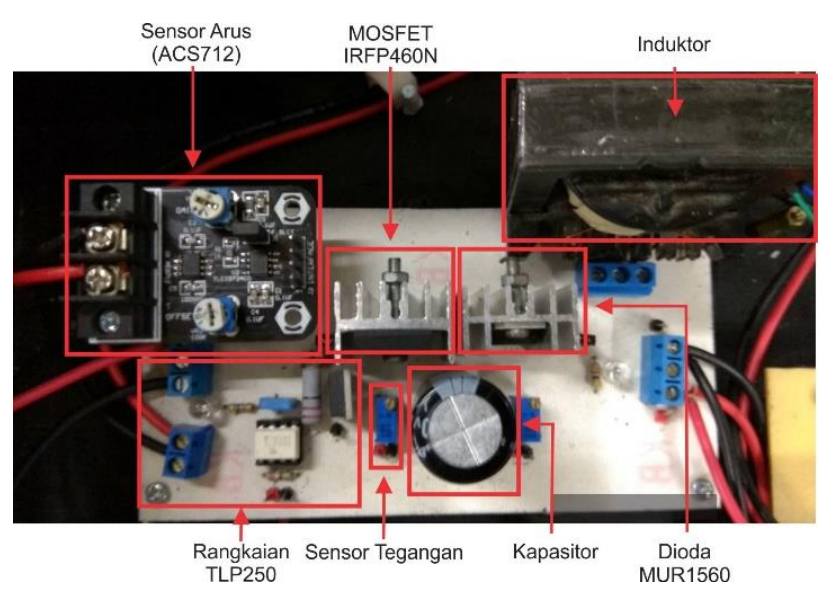

(b) Rangakian buck boost

Gambar 2. Buck boost converter

\subsection{Perencanaan Rangkaian Kontrol}

Rangkaian kontrol berfungsi untuk mendapatkan arus maksimal dan tegangan maksimal panel surya agar mencapai titik daya maksimum yang diinginkan. Rangkian kontrol dibagi menjadi tiga perencanaan, yaitu rangkaian sensor arus tegangan, rangakian Arduino Nano dan rangkaian driver.

\subsubsection{Sensor Arus dan Sensor Tegangan}

Sensor arus yang digunakan dalam penelitian ini adalah ACS712. Sensor arus ACS712 adalah sensor yang menggunakan metode Hall Effect Current Senso yaitu arus yang dibaca mengalir melalui kabel tembaga menghasilkan medan magnet kemudian ditangkap oleh integrated Hall IC dan diubah menjadi tegangan proporsional[6]. Data yang berupa tegangan analog tersebut terlebih dahulu melalui OP-AMP sebagai buffer, dan outputnya digunakan sebagai ADC rangkaian Arduino.

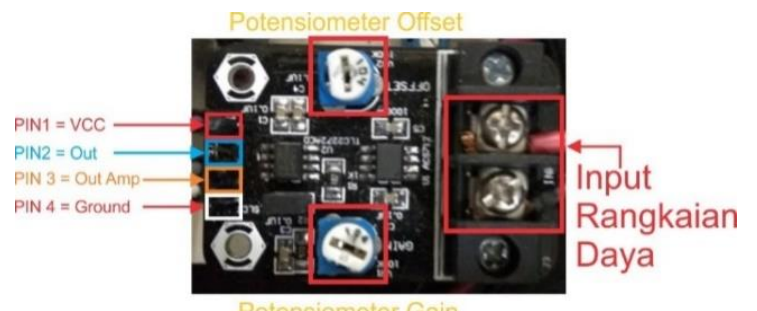

Gambar 3. Sensor ACS712 dan OpAmp

Sensor tegangan yang digunakan dalam penelitian Penelitian ini pada prinsipnya yaitu melakukan pencuplikan tegangan yang mengalir masuk ke sistem pengukuran. Rangkaian ini terdidi dari dua buah resistor yang berfungsi untuk membagi tegangan. Nilai input buck boost converter 21.56 volt tetapi dalam implementasinya sensor didesain untuk tegangan 22 volt, sehingga nilai dari $\mathrm{R} 15 \mathrm{k} \Omega$ dan $\mathrm{R} 2$ sebesar $17 \mathrm{k} \Omega$. Tegangan keluaran maksimal dari sensor tegangan sebesar $5 \mathrm{~V}$ yang nantinya sebagai input ADC mikrokontroler. Penlitian tugas akkhir ini dalam implementasi menggunakan multy turn sebagai rangkaian sensor tegangan.

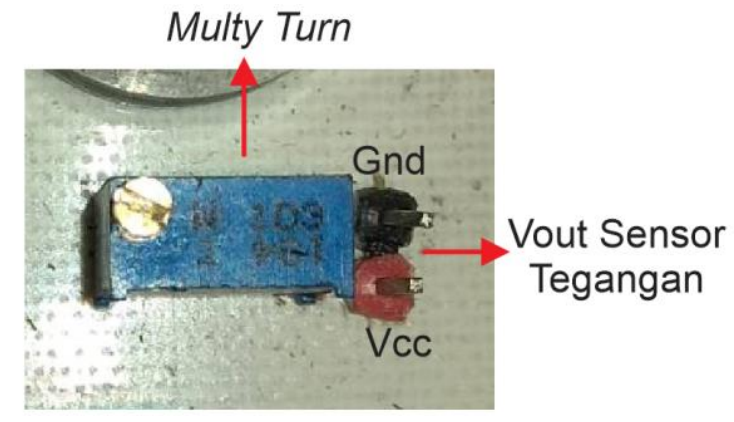

Gambar 4. Sensor Tegangan

\subsubsection{Sistem Rangkalian Arduino Nano}

Sistem rangkaian dalam penelitian Penelitian ini menggunakan Arduino Nano. Arduino sendiri memiliki peranan sebagai pengolahan data tegangan dan arus yang terbaca agar mencapai daya maksimum sesuai dengan tujuan awal. Komponen utama dari rangkaian adalah IC rangkaian ATMega328. Pada IC inilah semua program diisikan, sehingga dapat memproses semua data. Arduino Nano digunakan untuk mengolah data dan mengeksekusi sistem MPPT.
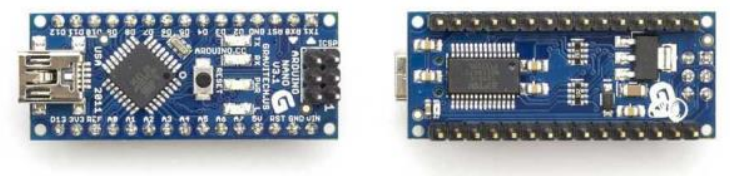

Gambar 5. Arduino Nano[7]

\subsubsection{Rangkaian Driver TLP250}

Rangkaian Driver yang digunakan dalam penelitian Penelitian ini mempunyai komponen utama yaitu TLP250 yang berfungsi untuk mengisolasi dan mengutkan sinyal PWM level tegangan 5 volt yang di bangkitkan rangkaian menjadi level tegangan yang lebih tinggi dengan sistem ground terpisah dan cukup untuk memicu MOSFET IRF460N yang membutuhkan tegangan VGS maksimal \pm $20 \mathrm{~V}$.

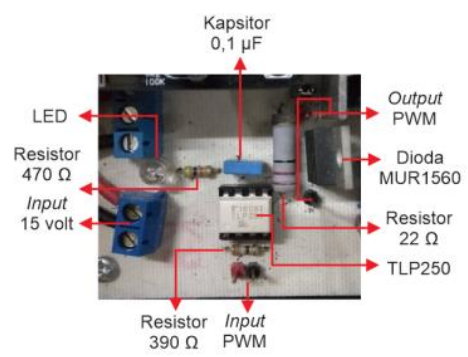

Gambar 6. Rangkaian Driver TLP250 


\subsection{Perencanaan Algoritma MPPT}

Algoritma MPPT yang digunakan dalam penelitian Penelitian ini adalah metode Perturb and Observe $\mathrm{P} \& \mathrm{O}$ berfungsi mencari titik daya maksimum. Metode P\&O digunakan untuk algoritma MPPT yang merupakan teknik pelacakan titik daya maksimum yang banyak digunakan hanya menggunakan sedikit parameter dan struktur umpan balik sederhana. Metode ini beroperasi dengan menambahkan atau mengurangi PWM secara periodic. Metode ini bekerja berdasarkan gradient kurva $P-V$ atau kurva $P-I$ karakteristik panel surya.

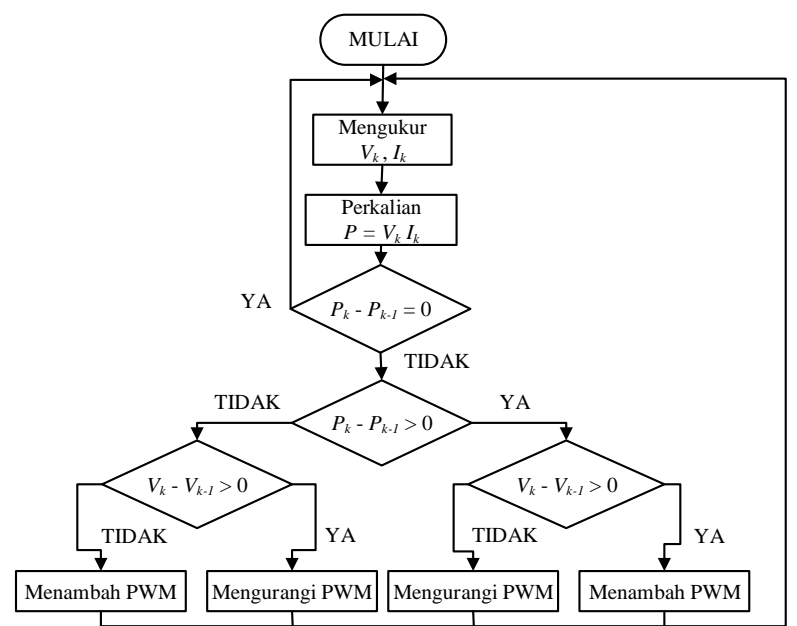

Gambar 7. Flowchart Algoritma MPPT Mode P\&O

\section{Hasil dan Analisis}

\subsection{Pengujian Penel Surya}

Pengujian panel surya dilakukan dengan menggunakan modul box panel surya. Pengambilan data yang dilakukan pertama kali adalah data spesifikasi dari panel surya yang digunakan pada waktu pengujian. Pengambilan data arus dan tegangan panel surya untuk mendapatkan kurva karakteristik I-V, setalah mendapat nilai arus dan tegangan maka didapat nilai dayanya, sehingga mendapatkan kurva P-V. Pengambilan dilakukan dengan iradiasi $1000 \mathrm{watt} / \mathrm{m}^{2}$ dan $750 \mathrm{watt} / \mathrm{m}^{2}$ serta temperatur dijaga konstan $29^{\circ} \mathrm{C}$.

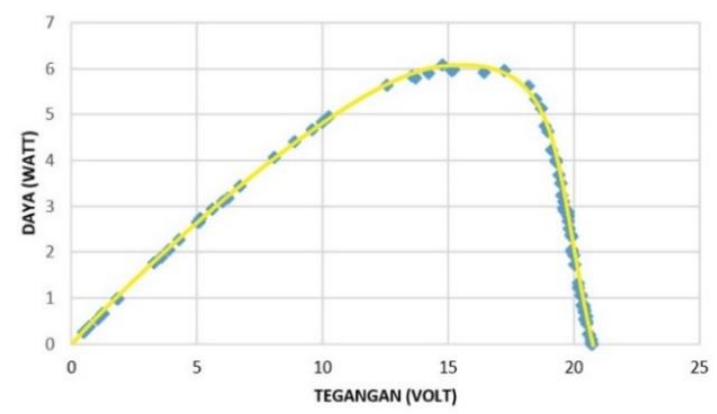

Gambar 8. Kurva daya dengan tegangan pada irradiasi 1000watt $/ \mathrm{m}^{2}$ temratur $29^{\circ} \mathrm{C}$
Pada Gambar 8 kurva daaya dengan tegangan dapat diperoleh daya maksimum pada titik 6.08 watt dengan tegangan $14.73 \mathrm{~V}$ dan arus 0.41 A pada saat irradiasi 1000 watt $/ \mathrm{m}^{2}$ dan temperatur $29^{\circ} \mathrm{C}$.

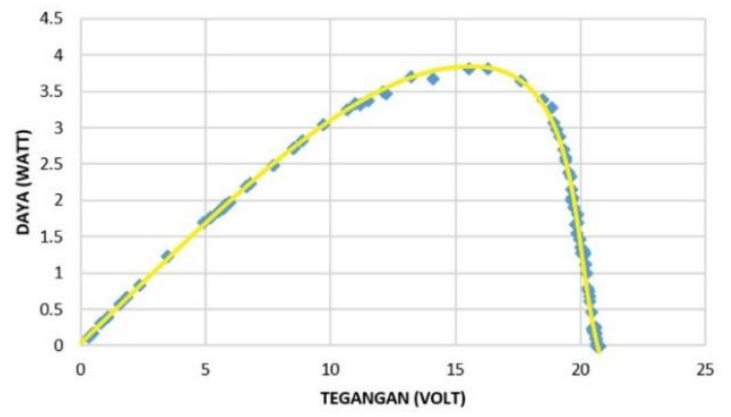

Gambar 9. Kurva daya dengan tegangan pada irradiasi 750watt $/ \mathrm{m}^{2}$ temratur $29^{\circ} \mathrm{C}$

Pada Gambar 9 kurva daaya dengan tegangan dapat diperoleh daya maksimum pada titik 3.81 watt dengan tegangan $15.52 \mathrm{~V}$ dan arus $0.25 \mathrm{~A}$ pada saat irradiasi 750 watt $/ \mathrm{m}^{2}$ dan temperatur $29^{\circ} \mathrm{C}$.

\subsection{Pengujian Rangkaian Kontrol}

Pengujian rangkaian kontrol dilakukan untuk mengetahui gelombang keluaran PWM rangkaian mikrokontroler, sensor arus, sensor tegangan dan keluaran PWM dari rangakian driver TLP250.

\subsubsection{Pengujian PWM Keluaran Mikrokontroler}

Gambar 10 menunjukan output pin D9 dimana pengamatan dilakukan pada V/div 2volt dan Time/div $10 \mu$ s dengan keluaran PWM 25\%.

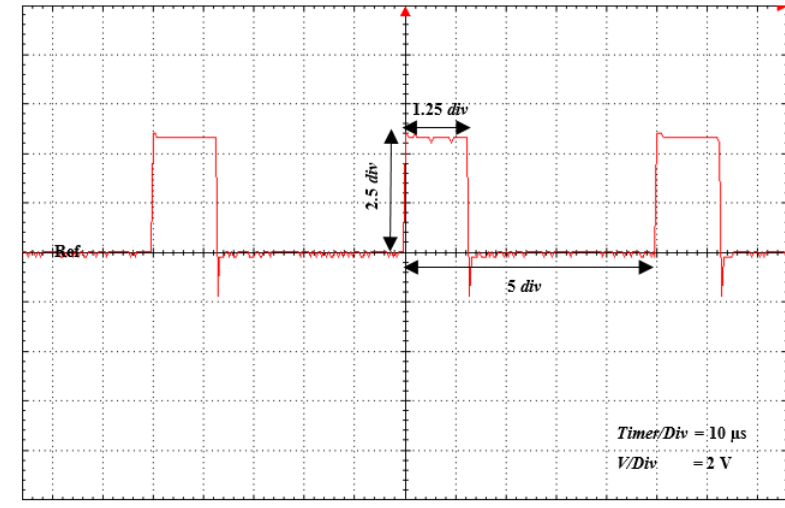

Gambar 10. Gelombang Keluaran PWM 25\% Mikrokontroler.

\subsubsection{Pengujian Sensor Arus}

Pengujian sensor arus dilakukan dengan menghubungkan sumber tegangan diseri dengan multimeter SANWA 
PC5000 dan sensor arus ACS712 kemudian diberi resistor sebagai beban. Variasi yang digunakan dalam pengujian ini adalah variasi tegangan masukan sehingga arus masukan juga berbeda tetapi dengan beban yang sama.

Tabel 4. Pengujian arus input dengan arus sensor pada beban $100 \Omega$.

\begin{tabular}{ccc}
\hline Arus Input (A) & Arus Sensor (A) & Error (\%) \\
\hline 0.3 & 0.3 & 0 \\
0.41 & 0.41 & 0 \\
0.51 & 0.51 & 0 \\
0.62 & 0.62 & 0 \\
0.71 & 0.71 & 0 \\
0.81 & 0.81 & 0 \\
0.9 & 0.9 & 0 \\
1.02 & 1.01 & 0.98 \\
1.1 & 1.09 & 0.91 \\
1.22 & 1.22 & 0.00 \\
\hline
\end{tabular}

Berdasarkan data Tabel didapatkan error rata-rata pembacaan sensor arus sebesar $0.19 \%$. Selisih nilai arus aktual dengan arus yang dibaca rangkaian disebabkan karena pembulatan nilai konstanta pada rangkaian yang tidak tepat dan pembacaan sensor arus ACS712 dipengaruhi oleh medan magnet disekitar sensor.

\subsubsection{Pengujian Sensor Tegangan}

Pengujian sensor tegangan dilakukan dengan mengukur sumber tegangan DC Power Suplay PS-500D dengan multimeter SANWA PC5000, kemudian mengukur sumber tegangan dengan sensor pembagi tegangan. Pengujian ini bertujuan untuk mengetahui kinerja dari tegangan yang dibuat. Pengujian dilakukan dengan membandingkan nilai tegangan multimeter SANWA PC5000 dengan nilai tegangan yang ditampilkan pada LCD.

Tabel 5. Pengujian arus input dengan arus sensor pada beban $100 \Omega$.

\begin{tabular}{ccc}
\hline Tegangan Input $(\mathbf{V})$ & Tegangan Sensor $(\mathbf{V})$ & Error $(\%)$ \\
\hline .12 & 0.12 & 0 \\
3.07 & 3.06 & 0.33 \\
4.12 & 4.12 & 0 \\
5.01 & 5.01 & 0 \\
6.07 & 6.08 & 0.16 \\
7.19 & 7.21 & 0.28 \\
8.11 & 8.13 & 0.25 \\
9.13 & 9.16 & 0.33 \\
\hline
\end{tabular}

Berdasarkan data Tabel 5, didapatkan error rata-rata pembacaan sensor tegangan $0.3 \%$. Error atau selisih nilai teganagn reverensi dengan nilai tegangan yang dibaca rangkaian disebabkan karena nilai dari sensor tegangan yang mempunyai toleransi dan pembulatan nilai serta konversi nilai analog kedigital pada saat perhitungan rangkaian.

\subsubsection{Pengujian Rangkaian Driver TLP250}

Gambar 11 menunjukan gelombang keluaran dari rangkaian driver TLP dimana pengamatan dilakukan pada V/div 5volt dan Time/div $10 \mu$ s dengan keluaran PWM $25 \%$.

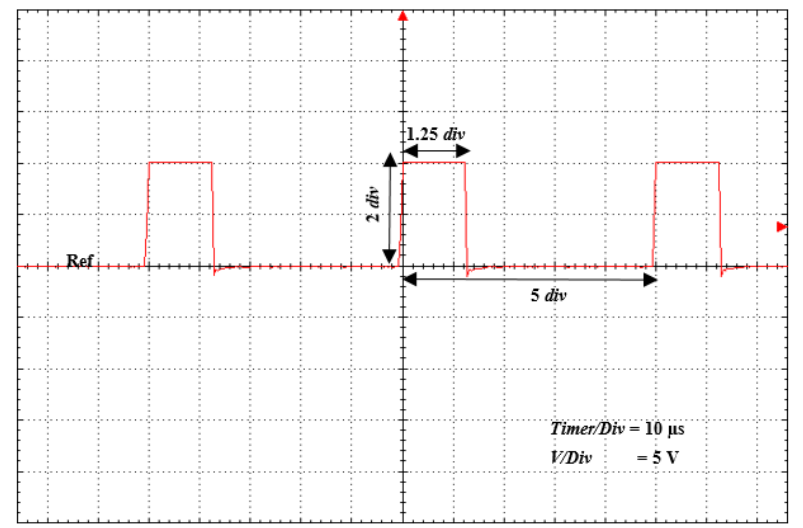

Gambar 11. Gelombang Keluaran PWM 25\% Rangkaian Driver TLP250.

\subsection{Pengujian Rangkaian Daya}

Pengujian rangkaian daya bertujuan untuk mengetahui karakteristik atau efisiensi rangkaian dari konverter buck boost yang telah dirancang. Pengujian rangakan daya dilakukan untuk mengukur tegangan masukan, arus masukan, tegangan keluaran, arus keluaran, dan perhitungan efisensi rangkaian buck boost converter.

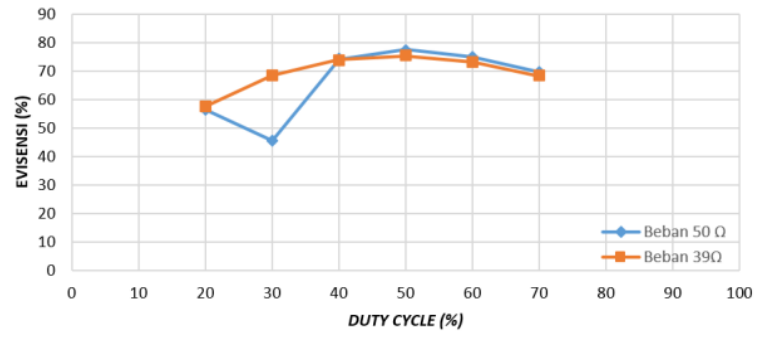

Gambar 12. Perbandingan efisensi rangkaian daya buck boost converter resistor $39 \Omega$ dengan $50 \Omega$.

Pada Gambar 12 didapatkan nilai rata-rata efisiensi dari buck boost converter dengan resistansi $39 \Omega$ sebesar $69.41 \%$ dan efisiensi maksimum sebesar $75.27 \%$, sedangkan pada nilai rata-rata efisensi buck boost converter dengan resistasi beban $50 \Omega$ sebesar $66.36 \%$ dan efisiensi maksimum $77.65 \%$. Nilai efisiensi tidak mencapai $100 \%$ disebabkan adanya daya yang terbuang dalam komponen buck boost converter. Daya yang berkurang pada saat switching disebabkan komponen MOSFET dan dioda buck boost converter. Komponen induktor menyebabkan terbuang daya, karena induktor yang digunakan memiliki nilai yang besar dan 
menyebabkan lilitannya bertambah banyak, sehingga resistansinya semakin besar.

\subsection{Pengujian Algoritma MPPT}

Algoritma MPPT yang digunakan pada penelitian Penelitian ini adalah Perturb and Observe ( $\mathrm{P} \& \mathrm{O})$. Pengujian algoritma MPPT ini bertujuan untuk membuktikan algoritma yang digunakan sudah mampu menjejak titik daya maksimum panel surya. Pengujian algoritma MPPT dilakukan dengan variasi iradiasi dan variasi nilai beban.

\subsubsection{Pengujian MPPT pada iradiasi 1000 watt $/ \mathrm{m}^{2}$ dan suhu $29^{\circ} \mathrm{C}$.}

Pengujian MPPT pada iradiasi 1000 watt $/ \mathrm{m}^{2}$ dan suhu $29^{\circ} \mathrm{C}$ dilakukan dengan 3 variasi nilai beban $100 \Omega, 50 \Omega$, dan $39 \Omega$.

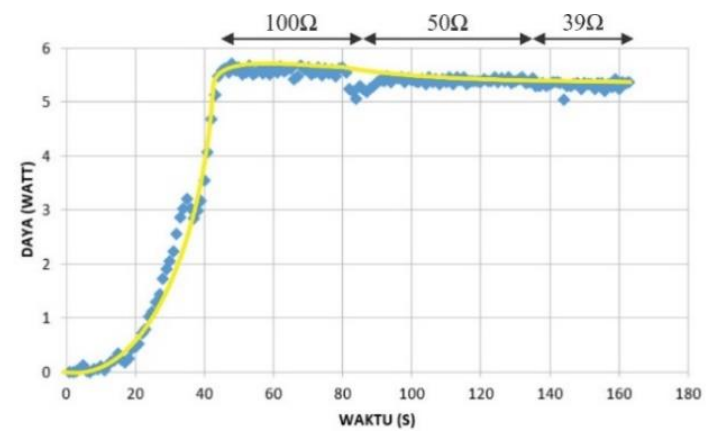

Gambar 13. Grafik MPPT pada iradiasi 1000 watt $/ \mathrm{m}^{2}$ dan suhu $29^{\circ} \mathrm{C}$.

Terdapat 4 kondisi pada saat pengambilan data, yaitu kondisi pertama saat mulai mencari daya dari nilai nol ke daya maksimum sehingga didapatkan daya maksimum sebesar 5.71 watt. Kondisi kedua pada saat MPPT mencapai daya maksimum tanpa ada perubahan beban atau dalam beban $100 \Omega$ daya maksimum rata-rata sebesar 5.57watt. Kondisi ketiga pada saat terjadi perubahan beban dari $100 \Omega$ menjadi $50 \Omega$ rata-rata daya maksimum sebesar 5.36watt. Kondisi keempat pada saat terjadi perubahan beban dari $50 \Omega$ menjadi $39 \Omega$ rata-rata daya maksimum sebesar 5.31watt.

\subsubsection{Pengujian MPPT pada iradiasi 750 watt $/ \mathrm{m}^{2}$ dan suhu $29^{\circ} \mathrm{C}$.}

Pengujian MPPT pada iradiasi $750 \mathrm{watt} / \mathrm{m}^{2}$ dan suhu $29^{\circ} \mathrm{C}$ dilakukan dengan 3 variasi nilai beban $100 \Omega, 50 \Omega$, dan $39 \Omega$.

Terdapat 4 kondisi pada saat pengambilan data, yaitu kondisi pertama saat mulai mencari daya dari nilai nol ke daya maksimum sehingga didapatkan daya maksimum sebesar 3.92 watt. Kondisi kedua pada saat MPPT mencapai daya maksimum tanpa ada perubahan beban atau dalam beban $100 \Omega$ daya maksimum rata-rata sebesar 3.83 watt. Kondisi ketiga pada saat terjadi perubahan beban dari $100 \Omega$ menjadi $50 \Omega$ rata-rata daya maksimum sebesar 3.67watt. Kondisi keempat pada saat terjadi perubahan beban dari $50 \Omega$ menjadi $39 \Omega$ rata-rata daya maksimum sebesar 3.63watt.

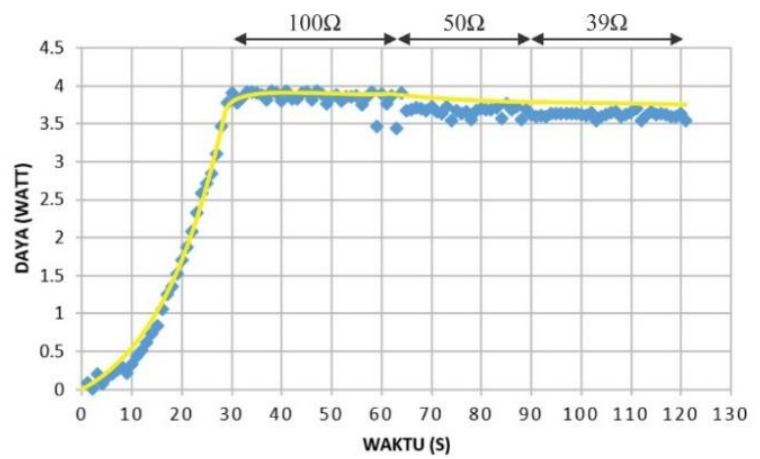

Gambar 14. Grafik MPPT pada iradiasi 750 watt $/ \mathrm{m}^{2}$ dan suhu $29^{\circ} \mathrm{C}$.

\subsubsection{Pengujian MPPT pada iradiasi 1000 watt $/ \mathrm{m}^{2}$ dan suhu $29^{\circ} \mathrm{C}$.}

Perbandingan daya keluaran panel surya dengan menggunakan metode MPPT dan tanpa MPPT bertujuan untuk mengetahui pengaruh dari variasi beban terhadap daya keluaran panel surya.

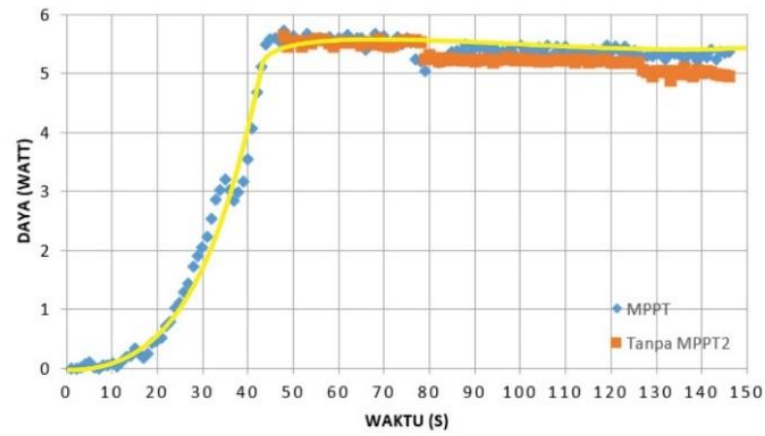

Gambar 15. Perbandingan daya keluaran dengan MPPT dan tanpa MPPT pada iradiasi 1000 watt $/ \mathrm{m}^{2}$.

Berdasarkan Gambar 15 Titik daya maksimum MPPT pada saat iradiasi $1000 \mathrm{watt} / \mathrm{m}^{2}$ pada beban $100 \Omega$ adalah 5.71 watt sedangkan ketika tanpa MPPT adalah 5.64 watt. Terdapat tiga kondisi perbandingan, kondisi pertama pada saat mencapai daya maksimum tanpa ada perubahan beban atau dalam beban $100 \Omega$ daya maksimum rata-rata dengan MPPT sebesar 5.71 watt dan tanpa MPPT sebsar 5.64 watt. Kondisi kedua pada saat terjadi perubahan beban dari 100 $\Omega$ menjadi $50 \Omega$ perbandingan daya keluaran rata-rata dengan MPPT sebesar 5.26 watt dan tanpa MPPT sebsar 5.22 watt. Kondisi ketiga pada saat terjadi perubahan beban dari $50 \Omega$ menjadi $39 \Omega$ perbandingan daya keluaran ratarata dengan MPPT sebesar 5.36 watt dan tanpa MPPT sebsar 4.99 watt. 


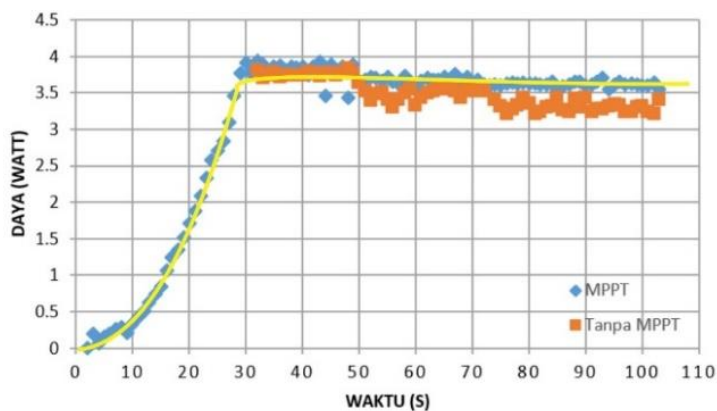

Gambar 15. Perbandingan daya keluaran dengan MPPT dan tanpa MPPT pada iradiasi 750 watt $/ \mathrm{m}^{2}$.

Berdasarkan Gambar 15 Terdapat tiga kondisi perbandingan, kondisi pertama pada saat mencapai daya maksimum tanpa ada perubahan beban atau dalam beban $100 \Omega$ daya maksimum rata-rata dengan MPPT sebesar 3.92 watt dan tanpa MPPT sebsar 3.81 watt. Kondisi kedua pada saat terjadi perubahan beban dari $100 \Omega$ menjadi 50 $\Omega$ perbandingan daya keluaran rata-rata dengan MPPT sebesar 3.67 watt dan tanpa MPPT sebsar 3.56 watt. Kondisi ketiga pada saat terjadi perubahan beban dari $50 \Omega$ menjadi $39 \Omega$ perbandingan daya keluaran rata-rata dengan MPPT sebesar 3.63 watt dan tanpa MPPT sebsar 3.38 watt.

\section{Kesimpulan}

Berdasarkan pengukuran dan analisis yang telah dilakukan maka dapat disimpulkan bahwa rangkaian Maximum Power Point Tracking dengan metode Perturb and Observe telah direalisasikan. Sistem MPPT mampu mencari daya maksimum rata-rata panel surya sebesar 4.395 watt pada iradiasi 1000 watt $/ \mathrm{m}^{2}$ suhu $29^{\circ} \mathrm{C}$, sedangkan tanpa MPPT pada beban $100 \Omega$ sebesar 5,63 watt, $50 \Omega$ sebesar 5,22 watt dan $29 \Omega$ sebesar 4,99 watt. Irradiasi 750 daya maksimum rata-rata panel surya sebesar 3.14 watt pada iradiasi 1000 watt $/ \mathrm{m}^{2}$ suhu $29^{\circ} \mathrm{C}$, sedangkan tanpa MPPT pada beban $100 \Omega$ sebesar 3.81 watt, $50 \Omega$ sebesar 3,56 watt dan $29 \Omega$ sebesar 3.38 watt. Upaya pengembangan sistem dan hardware lebih lanjut, maka dapat diberikan saran-saran bahwa penelitian ini dapat dikembangkan lagi dengan menambahkan penyetabil tegangan disisi output rangkaian daya dari MPPT.

\section{Referensi}

[1] I. Rahardjo and I. Fitriana, "Analisis Potensi Pembangkit Listrik Tenaga Surya Di Indonesia," Strateg. Penyediaan List. Nas. Dalam Rangka Mengantisipasi Pemanfaat. PLTU Batubara Skala Kecil, PLTN, dan Energi Terbarukan, P3TKKE, BPPT, Januari, pp. 43-52, 2005.

[2] S. Muhammad, "Pemanfaatan Solar Cell Sebagai Pembangkit Listrik Terbarukan," J. Tek. Jakarta, vol. 27 Nomor 3, 2014.

[3] S. Moring and A. Pols, "Maximum Power Point Tracking: Algorithm and Software Development," p. 66, 2012.

[4] T. Esram and P. L. Chapman, "Comparison of photovoltaic array maximum power point tracking techniques," IEEE Trans. Energy Convers., vol. 22, no. 2, pp. 439-449, 2007.

[5] D. C. Bani, M. Pujiantara, and H. Suryoatmojo, "MPPT Pada Sistem PV Menggunakan Algoritma Firefly dan Modified P\&O dengan Konverter Hybrid Cuk terkoneksi ke Grid Satu Phasa di Bawah Kondisi Partial Shaded," vol. 5, no. 2, 2016.

[6] I. Electronics, "DT-Sense Current Sensor," 2012.

[7] "Berkenalan dengan Arduino Nano," 2018. [Online]. Available: http://ecadio.com/mengenal-danbelajar-arduino-nano. [Accessed: 19-Aug-2018]. 